\title{
Recruitment of bay scallops Argopecten irradians in Floridan Gulf of Mexico waters: scales of coherence
}

\author{
William S. Arnold*, Dan C. Marelli, Catherine P. Bray**, Melissa M. Harrison \\ Florida Department of Environmental Protection, Florida Marine Research Institute, 100 Eighth Avenue Southeast, \\ St. Petersburg, Florida 33701-5095, USA
}

\begin{abstract}
Conventional wisdom suggests that pelagically borne marine invertebrate larvae are dispersed considerable distances from their source population, but recent research provides evidence that at least in some instances larvae may be retained within the local environment. From June 1995 through June 1996, we monitored adult abundance and juvenile recruitment in 4 geographically separated bay scallop Argopecten irradians populations occurring along the Gulf of Mexico coast of Florida, USA. Populations at our Anclote and Homosassa study sites had low adult abundances (generally $<5$ scallops per $600 \mathrm{~m}^{2}$ survey transect) during 1995 and 1996, whereas populations at our Steinhatchee and St. Joseph Bay study sites had considerably higher adult abundances (generally $>25$ scallops per $600 \mathrm{~m}^{2}$ survey transect) during those years. Similarly, recruitment to artificial spat collectors was a rare event at Anclote and Homosassa, where we typically collected fewer than 0.1 scallops per collector per day. In contrast, recruits were common at Steinhatchee and St. Joseph Bay, where daily recruitment rates exceeded those observed at Anclote and Homosassa by 1.5 to 2 orders of magnitude. Whereas differences in adult abundance and juvenile recruitment were pronounced among sites, differences among stations within each site were minor and generally not significant. Based upon these observations and knowledge of the distribution and abundance of bay scallops in Floridan Gulf of Mexico waters, our results suggest that during 1995-96, dispersal of bay scallop larvae was widespread within each study site but that transport of larvae away from the adult habitat was uncommon and ultimately unsuccessful. We discuss oceanographic features that may support local retention of bay scallop larvae along the west coast of Florida, and we suggest that periodic interruptions of those oceanographic processes may explain the previously reported genetic homogeneity among bay scallop populations in Florida
\end{abstract}

KEY WORDS: Dispersal · Recruitment $\cdot$ Argopecten irradians $\cdot$ Self-seeding

\section{INTRODUCTION}

Larvae of marine benthic invertebrates that possess complex life cycles have life spans ranging from days to weeks (Thorson 1950), exposing the planktonic stage to physical transport processes that may deposit them on substrates far from their source population (Scheltema 1971). Such transport is advantageous for maintaining gene flow among spatially separated pop-

-E-mail: arnold_b@epic7.dep.state.fl.us

- Present address: Florida Department of Environmental Protection, Apalachicola Shellfish Laboratory, 260 Seventh Street, Apalachicola, Florida 32320, USA ulations and for colonizing (or recolonizing) habitats (Scheltema 1971), but it may be disadvantageous if larvae are transported away from suitable habitats (Palmer \& Strathmann 1981). The generally accepted paradigm of larval dispersal is that planktotrophic larvae are transported considerable distances away from the adult population, with little likelihood of return to the parental habitat (Underwood \& Fairweather 1989). However, recent research indicates that larval retention within or near the adult habitat does occur in at least some situations (e.g. Olson 1985, Knowlton \& Keller 1986, Black et al. 1990, 1991, Peterson \& Summerson 1992, Schultz \& Cowen 1994, Parsons 1996). Because larval supply may be a primary determinant 
of subsequent adult abundance (Gaines \& Roughgarden 1985), a more complete understanding of larval dispersal patterns and scales, and subsequent larval supply, is necessary for the proper ecological and economic management of marine biological resources.

The concept of supply-side ecology (sensu Lewin 1986, but see Young 1987) formalizes the important role of larval supply in determining the ultimate structure of marine benthic communities. Considerable work on the role of larval supply in structuring the benthos, relative to more traditionally examined factors such as competition and predation, has been conducted on intertidal hard-bottom marine communities (e.g. Gaines \& Roughgarden 1985, Roughgarden et al. 1988, Sutherland 1990, Black \& Moran 1991, Minchinton \& Scheibling 1991, Bertness et al. 1992, Milicich et al. 1992). Much less information is available for softbottom communities (e.g. Peterson \& Summerson 1992), but the information that is available appears to support the importance of larval supply to resultant adult distribution and abundance (Snelgrove \& Butman 1994). More information is needed to fully understand the role that larval supply plays in determining community organization (Underwood \& Fairweather 1989), the influence of physical versus biological processes in regulating larval supply (Butman 1987), and the role of pre-versus post-settlement processes in determing marine benthic community structure (e.g. Olafsson et al. 1994). Obviously, post-settlement processes can only act on settled individuals, but predicting population abundance and community structure requires an understanding of the relative intensity of these various processes

A limiting factor in researching the role that larval supply plays in determining population abundance and community structure has been the difficulty involved in identifying and tracking the very small planktotrophic larvae of many marine invertebrates (Grosberg \& Levitan 1992). Some researchers have circumvented that problem in studies of larval supply to intertidal hard-bottom communities by concentrating research on a limited number of crustacean species that have morphologically defined larval stages, the larval dynamics of which provide the opportunity to test specific hypotheses concerning larval supply (e.g Gaines et al. 1985, Roughgarden et al. 1988, Minchinton \& Scheibling 1991, Gaines \& Bertness 1992). However, larvae of sessile molluscan species that commonly inhabit the soft-bottom benthos are more difficult to visually identify to the specific level than are their crustacean counterparts because the morphology of molluscan larvae is so similar among species (Chanley \& Andrews 1971). Alternative methods employing artificial substrates such as spat collectors (e.g. Brand et al. 1980) may be used to estimate larval supply, but those methods depend upon a close correlation between larval abundance and the resultant density of recruits to provide an accurate assessment of larval supply. That correlation will not be realized if larval settlement is strongly influenced by substrate selection during settlement or if post-settlement mortality patterns alter the proportion of settlers prior to sampling. The former problem may be alleviated by using a common substrate in all treatments, and the latter problem may be alleviated by sampling recruits very soon after settlement. For example, Harvey et al. (1995) have shown that survival of juvenile Iceland scallops Chlamys islandica is very high for at least 3 wk post-settlement, and Ambrose and colleagues (Ambrose \& Lin 1991, Ambrose et al. 1992) conclude that collectors deployed for up to $6 \mathrm{wk}$ provide valid estimates of relative settlement of bay scallops Argopecten irradians in North Carolina, USA, waters. Thus, by using qualitatively and quantitatively similar substrates and by deploying those substrates over a standardized and relatively short time period, valid estimates of larval supply may be obtained. Such an approach has been used in North Carolina waters to estimate larval supply of $A$. irradians to various estuarine soft-bottom habitats (Peterson \& Summerson 1992, Peterson et al. 1996).

Argopecten irradians is a simultaneous hermaphrodite that produces planktotrophic larvae with a larval duration of generally less than 2 wk (Sastry 1965) and an adult life span of generally less than 18 mo (Barber \& Blake 1983, Orensanz et al. 1991). In Gulf of Mexico, USA, waters, bay scallops are distributed as a series of disjunct local populations (sensu Hanski \& Simberloff 1997) within estuarine and nearshore habitats (Arnold et al. 1997). In aggregate, those local populations compose a metapopulation (Levins 1969, Hanski 1991) that at one time ranged from West Palm Beach on the southeast Atlantic Ocean coast of Florida to the Chandeleur Islands along the Gulf of Mexico coast of Louisiana (Waller 1969). In recent decades, many of those local populations have been severely depleted or have disappeared completely, and relatively high-density local populations are now limited to areas north and west of the Suwanee River (Arnold et al. 1997). Causative factors for the collapse of bay scallop populations south of the Suwanee River are not fully understood, but overfishing, habitat degradation, or toxic dinoflagellate blooms may be contributing factors. For example, bay scallops are generally confined to seagrass beds, and seagrass abundance on the west coast of Florida has decreased by up to $80 \%$ since the nineteenth century (Lewis et al. 1985). The loss of some local populations may have imperiled nearby populations that are dependent on the influx of allochthonous larvae for their longterm survival. Thus, although changes in the distribu- 
tion and abundance of bay scallops along the Gulf of Mexico coast of Florida may be due to natural or anthropogenic influences, the lack of recovery of those populations may reflect reductions in larval supply and subsequent recruitment failure. The inability of bay scallop populations in other western Atlantic coastal areas to rapidly recover from toxic algal blooms (North Carolina. Summerson \& Peterson 1990; New York: Tettelbach \& Wenczel 1993) has similarly been attributed to an inadequate larval supply (Peterson \& Summerson 1992, Tettelbach \& Wenczel 1993, Peterson et al. 1996). Intervention may be required to reestablish depleted bay scallop populations throughout Atlantic and Gulf of Mexico coastal areas, but intervention strategies must be based upon sound ecological principles (Peterson et al. 1996).

In 1995 the Florida Marine Fisheries Commission revised rules regarding bay scallop harvest in Florida to eliminate all commercial fishing for the species within state waters and to limit the popular recreational fishery to

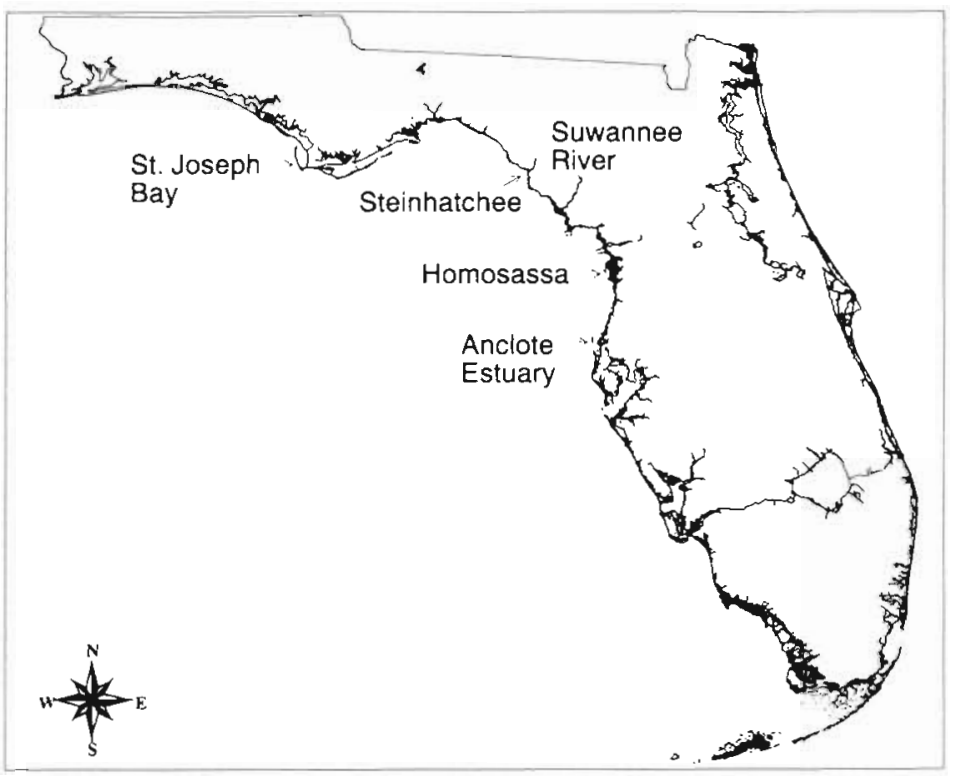

Fig. 1. Map of Florida, USA, showing sample locations for bay scallop Argopecten irradians adult monitoring and recruitment study and other geographic reference points mentioned in the text

areas north and west of a closure line extending westward from the mouth of the Suwanee River. The intent of those rule revisions was to eliminate fishing pressure on low-density populations (generally $<5$ scallops per $600 \mathrm{~m}^{2}$ ) and to reduce pressure on those few remaining high-density populations (generally $>5$ scallops per $600 \mathrm{~m}^{2}$ and commonly with densities exceeding 100 scallops per $600 \mathrm{~m}^{2}$ ). We have initiated a research program to monitor the recovery of depleted bay scallop populations in Florida, to determine biological factors that may influence recovery, and to provide the basic biological and ecological information necessary for the effective design and implementation of a restoration strategy. We report here on the results of a study comparing adult density within and among each of 4 sites along the Gulf of Mexico coast of Florida during 1995 and 1996, and we discuss the potential influence of larval supply (as estimated by recruitment to artificial spat collectors) on the observed distribution and abundance of those populations.

\section{MATERIALS AND METHODS}

Adult population surveys. Adult scallop populations were surveyed during June 1995 and June 1996 at each of 4 sites along the Gulf of Mexico coast of Florida (Fig. 1). South of the Suwanee River closure line, populations were monitored at Anclote Estuary and at Homosassa Bay. North of the closure line, populations were monitored at Deadman's Bay near Steinhatchee and in St. Joseph Bay. Adult densities were determined at each of 20 randomly allocated and geographically referenced stations located between the $0.61 \mathrm{~m}$ and the $1.83 \mathrm{~m}$ depth contours within each site (Figs. 2 to 5); stations were repetitively sampled each year. At each survey station, 2 SCUBA divers swam the length of a $300 \mathrm{~m}$ transect line arranged in a triangular manner, with 1 diver on either side of the line counting all scallops within $1 \mathrm{~m}$ of the line. Total area surveyed at each station was $600 \mathrm{~m}^{2}$ and at each site was $12000 \mathrm{~m}^{2}$.

For statistical comparisons, adult population density data were first $\log (n+1)$ transformed to minimize heteroscedasticity (Sokal \& Rohlf 1995) and then were compared among sites and between years using 2-way fixed-effects Analysis of Variance (ANOVA) with year (1995, 1996) and site (Anclote, Homosassa, Steinhatchee, St. Joseph Bay) as factors. We also compared $\log (\mathrm{n}+1)$ transformed adult density data among sites within each year using 1-way fixed-effects ANOVA. When appropriate, significant main effects were compared for differences among means with the stepwise Ryan's Q test at alpha $=0.05$ (Day \& Quinn 1989).

Recruitment monitoring. Bay scallop recruitment to spat collector bags, as an index of settlement (Keough \& Downes 1982), was monitored at each site during late summer of 1995 through late winter of 1996 . We measured recruitment as the rate of recovery of juvenile bay scallops from spat-collector bags deployed at each of our 4 study sites. For that purpose, we used 


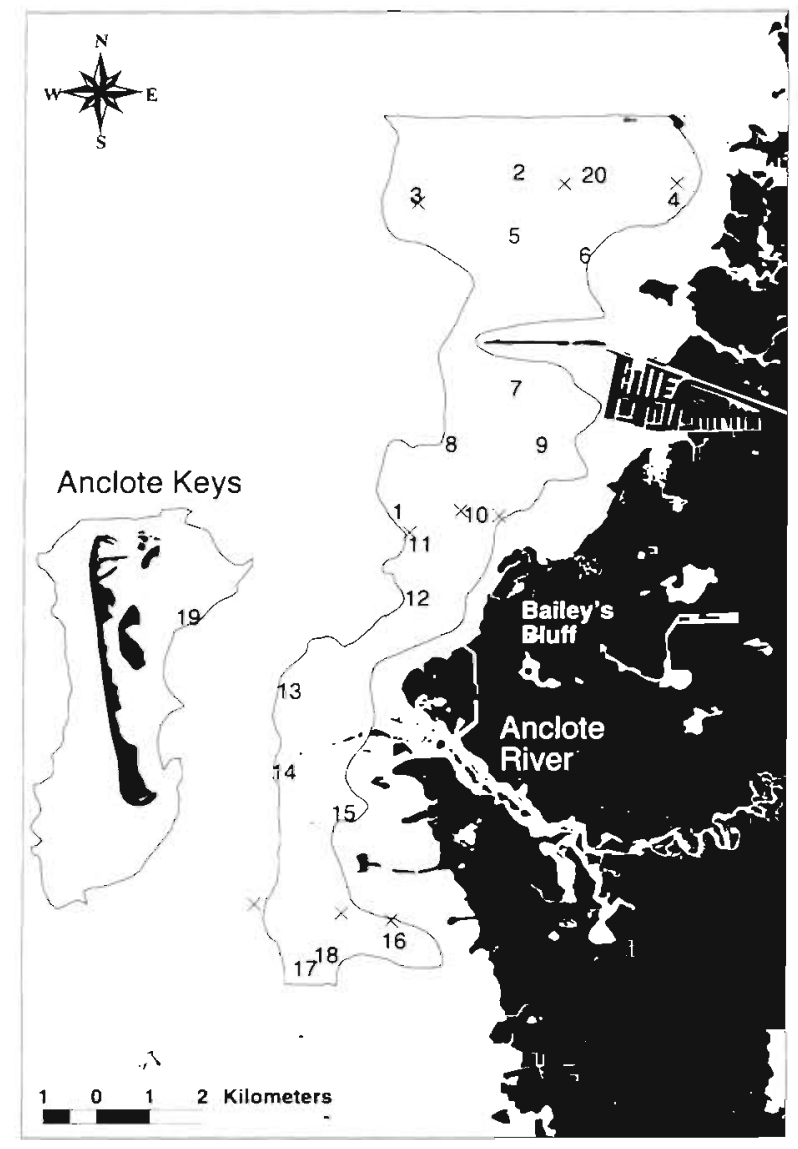

Fig. 2. Map of the Anclote Estuary study site showing station locations for bay scallop Argopecten irradians adult abundance surveys conducted during June 1995 and June 1996 , and recruitment monitoring studies conducted during fall 1995. Numbers denote sample station number and location for adults surveys, and crosses depict locations of spat-collector stations

spat collectors similar to those successfully employed in numerous previous studies (e.g. Brand et al. 1980, Ambrose et al. 1992, Peterson \& Summerson 1992). Collectors were constructed from presoaked (Parsons et al. 1993, Harvey et al. 1997) $30 \times 48 \mathrm{~cm}$ panels of $4 \mathrm{~mm}$ mesh polypropylene encased within a $4 \mathrm{~mm}$ mesh citrus bag (Ambrose et al. 1992). Each collector was attached at one end to a small plastic donut float that served to maintain the collector in a vertical position and at the other end to a length of $6.35 \mathrm{~mm}$ diameter polypropylene rope. The rope was attached to a cinder-block anchor and to a crab-trap float that maintained the generally vertical position of the collector in the water column and provided for surface location and retrieval. A single collector was positioned $0.5 \mathrm{~m}$ above the anckor on each line.

Collector arrays were deployed in triplicate at 9 stations at the Anclote, Homosassa, and Steinhatchee study sites and at 4 stations at the St. Joseph Bay study

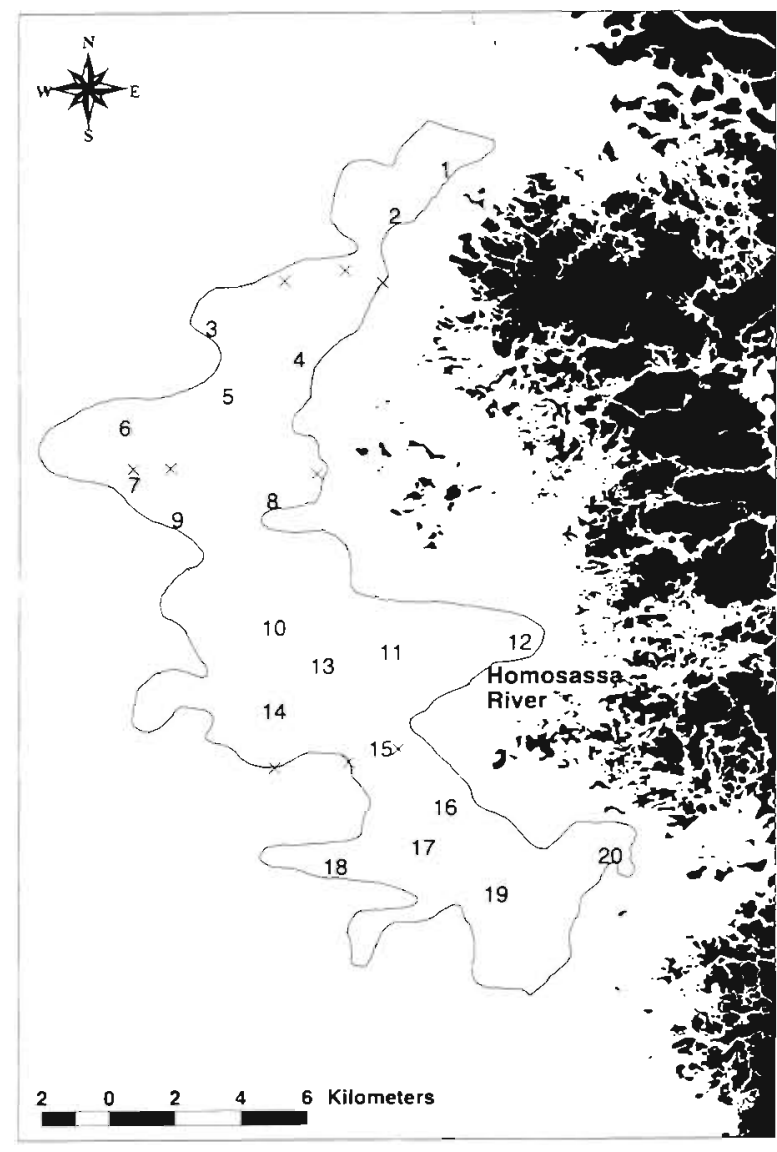

Fig. 3. Map of the Homosassa study site showing station locations for bay scallop Argopecten irradians adult abundance surveys conducted during June 1995 and June 1996. and recruitment monitoring studies conducted during fall 1995. Numbers denote sample station number and location for adults surveys, and crosses depict locations of spat-collector stations

site. At each of the Anclote, Homosassa, and Steinhatchee study sites, bay scallop populations occur in relatively discrete beds that parallel the coast and are generally confined between the 0.5 and $1.5 \mathrm{~m}$ depth contours. Spat-collector stations were located along latitudinal transects perpendicular to the coast and near the north end, center, and south end of the scallop 'bed' at each of those sites (Figs. 2 to 4). Stations were positioned in depths of $0.5,1.0$, and $1.5 \mathrm{~m}$ along each of the 3 latitudinal transects at each site. In St. Joseph Bay, bay scallops are cenerally distributed within a narrow band of relatively shallow water along the southeastern, southern, and southwestern shores of the bay. We positioned spat collectors at 4 stations within that band and at a depth of approximately $1.0 \mathrm{~m}$ at each station (Fig 5). In all cases, collectors were deployed within seagrass beds to avoid differences in collector efficiency between vegetated and unvegetated habitats (Ambrose et al. 1992). 


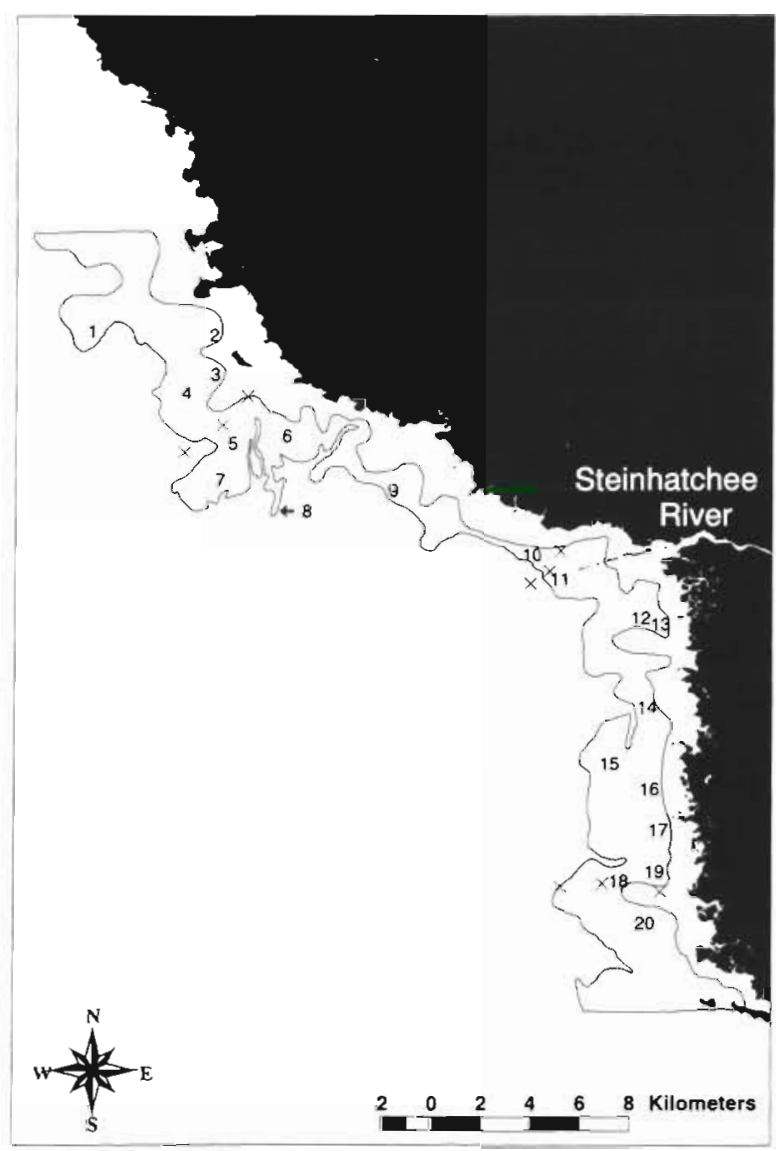

Fig. 4. Map of the Steinhatchee study site showing station locations for bay scallop Argopecten irradians adult abundance surveys conducted during June 1995 and June 1996, and recruitment monitoring studies conducted during fall 1995. Numbers denote sample station number and location for adults surveys, and crosses depict locations of spat-collector stations

Two sets of collectors were deployed, at each spatmonitoring station, on a 3 wk overlapping schedule. Thus, one set of 3 replicates was deployed at each station, and then 3 wk later a second set of 3 replicates was deployed at that same station. Each set of collectors was allowed to soak for $6 \mathrm{wk}$ prior to recovery. This arrangement was necessary to ensure that all settlement events were recorded despite our inability to recognize very small spat that may have settled just

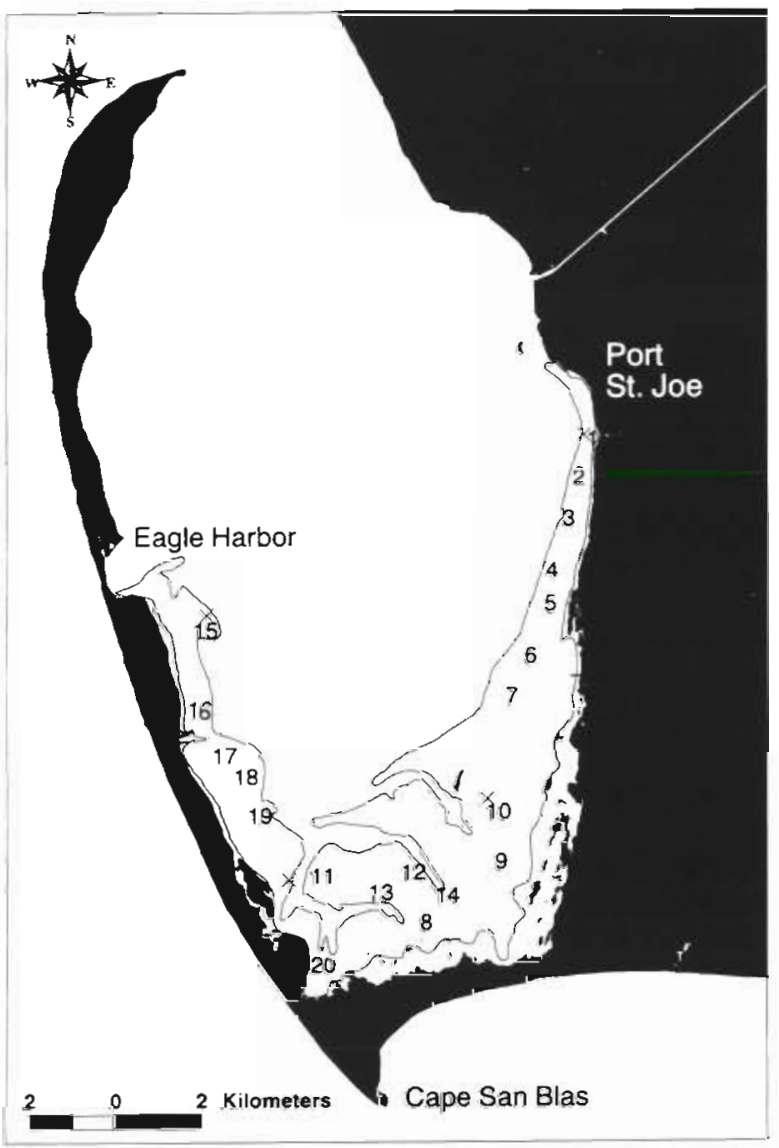

Fig. 5. Map of the St. Joseph Bay study site showing station locations for bay scallop Argopecten irradians adult abundance surveys conducted during June 1995 and June 1996, and recruitment monitoring studies conducted during fall 1995. Numbers denote sample station number and location for adults surveys, and crosses depict locations of spat-collector stations

prior to recovery of a collector. Any settlement event that occurred just prior to recovery of one group of collectors would be equally recorded on the complementary group. The complementary group would not be recovered for an additional $3 \mathrm{wk}$, providing ample time for the spat to grow to a detectable size. We report here on 6 complete deployment-recovery sequences conducted between August 1995 and February 1996 (Table 1)

Table 1. Deployment and recovery dates $(\mathrm{mo} / \mathrm{d})$ for spat collectors at 4 sites along the Floridan Gulf of Mexico coast. Project dates began in fall 1995 and continued through early winter 1996. See Fig. 1 for site locations

\begin{tabular}{|c|c|c|c|c|c|c|}
\hline $\mathrm{De}$ & nent: 1 & 2 & 3 & 4 & 5 & 6 \\
\hline Anclote & $8 / 11-9 / 29$ & $9 / 5-10 / 27$ & $9 / 29-11 / 16$ & $10 / 27-12 / 13$ & $11 / 16-1 / 11$ & $12 / 13-2 / 1$ \\
\hline Homosassa & $8 / 16-9 / 27$ & $9 / 8-10 / 20$ & $9 / 27-11 / 8$ & $10 / 20-11 / 28$ & $11 / 8-12 / 29$ & $11 / 28-1 / 18$ \\
\hline Steinhatchee & $8 / 15-9 / 26$ & $9 / 7-10 / 21$ & $9 / 26-11 / 7$ & $10 / 21-11 / 29$ & $11 / 7-12 / 28$ & $11 / 29-1 / 17$ \\
\hline St. Joseph Bay & $8 / 10-9 / 26$ & $8 / 30-10 / 11$ & $9 / 26-11 / 10$ & $10 / 11-11 / 19$ & $11 / 10-12 / 29$ & $11 / 19-1 / 14$ \\
\hline
\end{tabular}


Upon recovery, each spat collector was placed in an individual black household garbage bag along with an identification label and was then returned to the laboratory. The samples were not otherwise preserved. Although tissue degradation was unavoidable, the juvenile shells were preserved almost exclusively in the paired condition. Each polypropylene panel was then thoroughly examined with the aid of a magnification lamp, and all identifiable scallop spat were removed, counted, and stored in a labelled vial. Any spat recovered from the inside or outside of the citrus bag, or found loose in the holding bag, were noted as to position, counted, and similarly stored. Occasional unpaired valves were counted and the total per collector was divided by 2 and rounded up to the nearest whole number to provide an estimate of their contribution to the total count of whole scallops.

Recruitment data were normalized to a daily recruitment rate by dividing the total number of spat from each collector by the number of days deployed. Within each site, daily recruitment rate was compared among stations (St. Joseph Bay) using a 1-way repeated measures multivariate ANOVA or among depth and latitudinal position (Anclote, Homosassa, Steinhatchee) using a 2-way repeated measures multivariate ANOVA (Zar 1996) with date as the repeated measure and both latitudinal transect and deployment depth as fixed effects. We report our results using the Wilks'
Lambda statistic because those results are based upon a likelihood-ratio approach (Littell et al. 1991) and in all cases were very similar to results derived from Pillai's Trace or the Hotelling-Lawley Trace. Recruitment data were analyzed separately within each site to eliminate the influence of artificial relationships among latitudinal transect positions at each site. Data from the Steinhatchee and St. Joseph Bay populations were square-root $(n+0.5)$ transformed to minimize heteroscedasticity, but transformation was not required prior to analysis of the Anclote and Homosassa data. All statistical analyses were conducted using the SAS version 6 statistical analysis software (SAS Institute 1996).

\section{RESULTS}

\section{Adult population surveys}

In both 1995 and 1996, adult bay scallops were far less abundant at the Anclote and Homosassa study sites than they were at Steinhatchee and St. Joseph Bay (Table 2). When averaged among all 20 sampling stations within each site, scallop densities were consistently $<5$ per $600 \mathrm{~m}^{2}$ during both years at Anclote and Homosassa, whereas scallop densities in excess of 25 per $600 \mathrm{~m}^{2}$ were typical at Steinhatchee and St. Joseph

Table 2. Abundance (no. per $600 \mathrm{~m}^{2}$ ) of bay scallops Argopecten irradians at each of 20 stations sampled at each of 4 study sites during 1995 and 1996. See Fig. 1 for site locations, and Figs. 2 to 5 for station locations within each site. Mean and sample standard deviation are summarized at the bottom of the table

\begin{tabular}{|c|c|c|c|c|c|c|c|c|}
\hline \multirow[t]{2}{*}{ Station number } & \multicolumn{2}{|c|}{ Anclote } & \multicolumn{2}{|c|}{ Homosassa } & \multicolumn{2}{|c|}{ Steinhatchee } & \multicolumn{2}{|c|}{ St. Joseph Bay } \\
\hline & 1995 & 1996 & 1995 & 1996 & 1995 & 1996 & 1995 & 1996 \\
\hline 1 & 0 & 4 & 0 & 0 & 13 & 528 & 1 & 4. \\
\hline 2 & 0 & 3 & 9 & 2 & 48 & 36 & 1 & 64 \\
\hline 3 & 0 & 2 & 9 & 5 & 16 & 128 & 6 & 2 \\
\hline 4 & 0 & 0 & 4 & 0 & 14 & 269 & 2 & 0 \\
\hline 5 & 0 & 0 & 14 & 5 & 14 & 1879 & 67 & 2 \\
\hline 6 & 0 & 0 & 1 & 9 & 22 & 210 & 205 & 114 \\
\hline 7 & 0 & 0 & 2 & 5 & 4 & 73 & .114 & 55 \\
\hline 8 & 0 & 12 & 27 & 4 & 1 & 0 & 348 & 156 \\
\hline 9 & 3 & 0 & 7 & 4 & 44 & 498 & 118 & 43 \\
\hline 10 & 0 & 1 & 3 & 2 & 0 & 76 & 711 & 363 \\
\hline 11 & 0 & 2 & 1 & 0 & 0 & 0 & 5 & 759 \\
\hline 12 & 0 & 0 & 1 & 3 & 0 & 415 & 233 & 1136 \\
\hline 13 & 0 & 0 & 6 & 2 & 8 & 41 & 195 & 354 \\
\hline 14 & 0 & 11 & 0 & 9 & 4 & 119 & 270 & 820 \\
\hline 15 & 0 & 1 & 1 & 2 & 1 & 65 & 11 & 44 \\
\hline 16 & 0 & 23 & 3 & 0 & 30 & 71. & 14 & 228 \\
\hline 17 & 0 & 6 & 1 & 6 & 23 & 118 & 44 & 282 \\
\hline 18 & 0 & 3 & 3 & 3 & 3 & 44 & 25 & 230 \\
\hline 19 & 0 & 0 & 2 & 1 & 313 & 284 & 17 & 179 \\
\hline 20 & 0 & 0 & 0 & 0 & 27 & 151 & 257 & 103 \\
\hline Mean & 0.2 & 3.4 & 4.7 & 3.1 & 29.2 & 250.2 & 132.2 & 246.9 \\
\hline SD & 0.7 & 5.8 & 6.4 & 2.8 & 68.3 & 414.6 & 175.5 & 312.2 \\
\hline
\end{tabular}


Table 3. Results of ANOVA testing whether adult bay scallops Argopecten irradians were equally distributed among study sites (Anclote, Homosassa, Steinhatchee, St. Joseph Bay) during 1995 and 1996, as determined by $600 \mathrm{~m}^{2}$ transect surveys at each of 20 stations within each site

\begin{tabular}{|lrrrrr|}
\hline $\begin{array}{l}\text { Source of } \\
\text { variation }\end{array}$ & df & SS & MS & $F$ & Significance \\
\hline Year & 1 & 32.65 & 32.65 & 16.60 & 0.0001 \\
Site & 3 & 348.88 & 116.29 & 59.12 & 0.0001 \\
Year $\times$ Site & 3 & 28.98 & 9.66 & 4.91 & 0.0028 \\
Error & 152 & 298.99 & 1.97 & & \\
\hline
\end{tabular}

Bay in both years. Adult density never exceeded 27 scallops per transect at any station in Anclote or Homosassa, whereas more than 500 scallops were recorded from each of several stations at both Steinhatchee and St. Joseph Bay. Overall, scallops were significantly more abundant at our 4 sites in 1996 than in 1995; scallop abundance increased from 1995 to 1996 at each of the Anclote, Steinhatchee, and St. Joseph Bay study sites but decreased at the Homosassa site, which explains the significance of the site $\times$ year interaction term (Table 3). Within each year, adult scallop abundance differed significantly among sites during both 1995 and 1996 (Table 4). During 1995 scallop abundance differed significantly among all sites, whereas during 1996 scallops were equally abundant at Steinhatchee and St. Joseph Bay but were significantly more abundant at those sites than at Homosassa and Anclote (Table 5).

\section{Recruitment monitoring}

The magnitude of recruitment at each site reflected patterns of adult abundance. Spatfall to collectors was rare at Anclote (Fig. 6), where spat were recovered from only 22 of 51 sampling opportunities (a sampling opportunity represents any date $\times$ station combination where at least 1 collector was retrieved), and an extremely rare event at Homosassa, where spat were recovered from only 4 of 52 sampling opportunities (Fig. 7). Even on those dates when spat were recovered, recruitment rates were very low at both Anclote and Homosassa and never exceeded 0.11 spat $\mathrm{d}^{-1}$. In contrast, spat were recovered from 41 of 54 sampling opportunities at Steinhatchee (Fig. 8) and from 22 of 24 sampling opportunities at St. Joseph Bay (Fig. 9). Moreover, rate of recruitment was substantially higher at both Steinhatchee and St. Joseph Bay than at either Anclote or Homosassa. Maximum daily recruitment

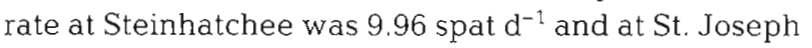
Bay was 37.34 spat $d^{-1}$.
Table 4. Results of ANOVA testing whether adult bay scallops Argopecten irradians were equally distributed among study sites (Anclote, Homosassa, Steinhatchee, St. Joseph Bay) within each of the 1995 and 1996 study years, as determined by $600 \mathrm{~m}^{2}$ transect surveys at each of 20 stations within each site

\begin{tabular}{|lrrrrr|}
\hline $\begin{array}{l}\text { Source of } \\
\text { variation }\end{array}$ & df & SS & MS & $F$ & Significance \\
\hline $\mathbf{1 9 9 5}$ & & & & & \\
Site & 3 & 144.29 & 48.10 & 28.64 & 0.0001 \\
Error & 76 & 127.61 & 1.68 & & \\
$\mathbf{1 9 9 6}$ & & & & & \\
Site & 3 & 233.57 & 77.86 & 34.53 & 0.0001 \\
Error & 76 & 171.38 & 2.26 & & \\
\hline
\end{tabular}

Rate of recruitment to spat collectors deployed at the Anclote study site varied significantly with time ( $F=$ $17.39, p=0.0035$ ), but no significant interactions between time and latitudinal position $(F=1.84, \mathrm{p}=0.18)$ or between time and deployment depth $(F=1.42, \mathrm{p}=$ 0.29 ) were detected. Using a means transformation (Littell et al. 1991), we determined that, during our first deployment, recruitment at Anclote was significantly lower than the mean of the remaining dates but that a recruitment pulse was detected at most stations during the second deployment (Fig. 6). That pulse was not sustained through the third deployment, but another pulse was detected during the fourth deployment and sustained through the fifth deployment before again declining during the final deployment. During the entire sampling period, recruitment was most consistent along the central latitudinal transect, but recruitment of at least 0.10 scallops $\mathrm{d}^{-1}$ was observed from all latitudinal transects (though not necessarily from every station along each of those transects) on at least 1 date.

Table 5. Ryan's Multiple Range Q-test for differences among 4 sites (Anclote Estuary, Homosassa, Steinhatchee, and St. Joseph Bay) in abundance of adult bay scallops sampled from 20 stations within each site (see Figs. 2 to 5 for locations of sample stations within each site) during June 1995 and June 1996. Significance was determined at alpha $=0.05$

\begin{tabular}{|lrrrc|}
\hline Site & $\begin{array}{c}\text { Mean } \\
\text { abundance }\end{array}$ & SD & N & $\begin{array}{c}\text { Ryan's } Q \\
\text { grouping }\end{array}$ \\
\hline 1995 & & & & \\
Anclote Estuary & 0.15 & 0.67 & 20 & A \\
Homosassa & 4.70 & 6.43 & 20 & B \\
Steinhatchee & 29.25 & 68.31 & 20 & $\mathrm{C}$ \\
St. Joseph Bay & 132.20 & 175.47 & 20 & D \\
1996 & & & & \\
Anclote Estuary & 3.40 & 5.82 & 20 & A \\
Homosassa & 3.10 & 2.79 & 20 & A \\
Steinhatchee & 250.25 & 414.65 & 20 & B \\
St. Joseph Bay & 246.90 & 312.22 & 20 & B \\
\hline
\end{tabular}



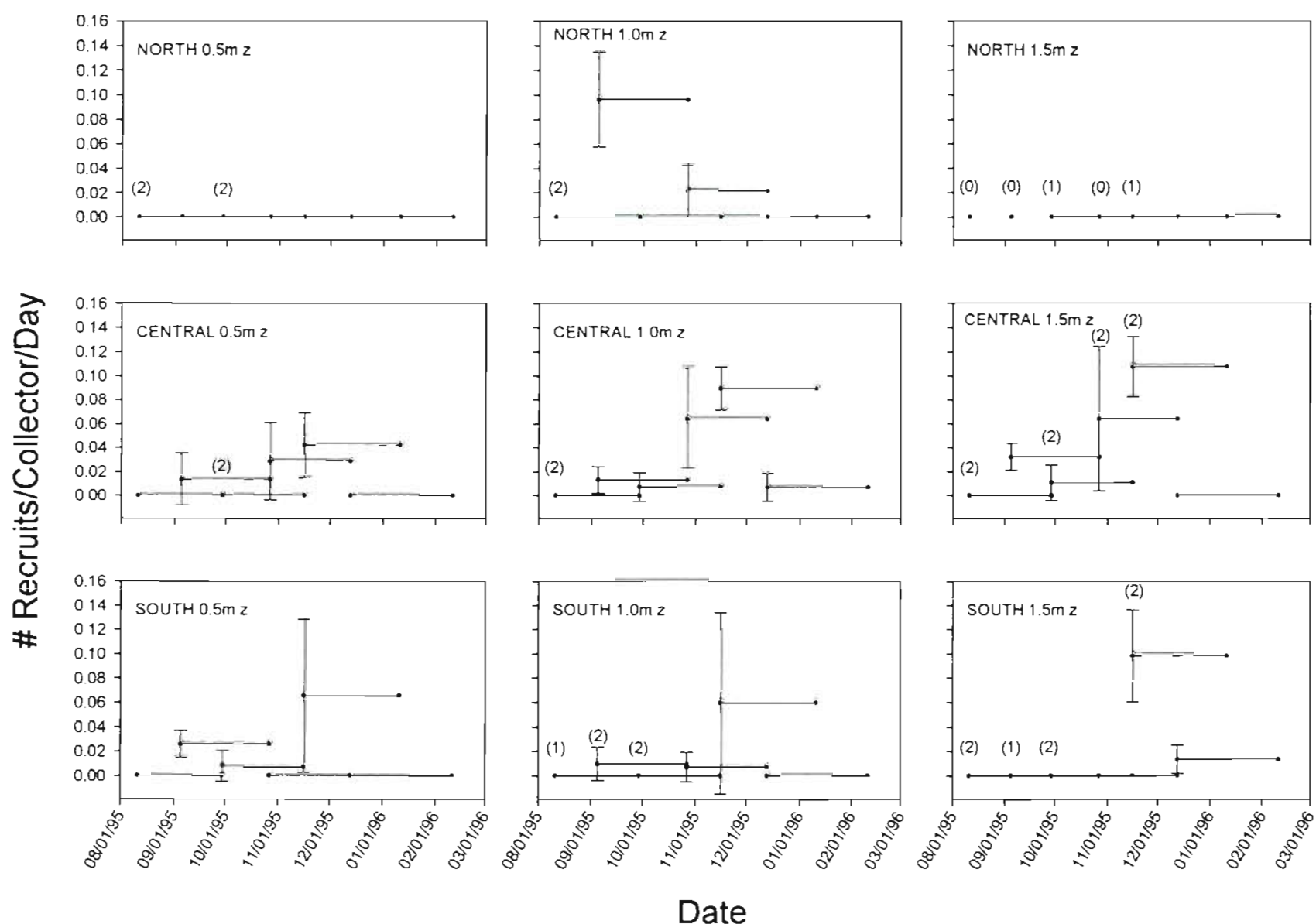

Fig. 6. Recruitment of bay scallops Argopecten irradians to spat collectors deployed at each of 9 stations at the Anclote Estuary study site during August 1995 to February 1996. Spat-collector station locations are arrayed according to latitudinal position and water depth; locations are depicted in Fig. 2. Each 6 wk deployment is denoted by a start-date point (mo/d/yr), an end-date point, and a line connecting the 2 points. Error bars represent 1 standard deviation from the mean and are positioned at the start point of the deployment period they represent. Numbers in parentheses represent number of collectors recovered from that deployment period, are similarly positioned at the beginning point of the deployment period they represent, and are not included for deployments from which all 3 collectors were recovered

Recruitment was not detected at the northeast and northwest Anclote stations, although low numbers at the latter station may be partly explained by extensive loss of collectors during the first 4 deployments (Fig. 6).

Recruitment rate at Homosassa was not significantly affected by time of collection $(F=0.27, \mathrm{p}=0.85)$, and no significant interactions between time and latitudinal position $(F=0.33, \mathrm{p}=0.90)$ or between time and deployment depth $(F=0.85, p=0.57)$ were detected. Recruitment was 0 at most stations during most sampling episodes (Fig. 7). A very low level of recruitment (less than 0.04 recruits $\mathrm{d}^{-1}$ ) was detected at some stations during the first 2 deployments (Fig. 7), after which we detected only 1 small event at the northeast station during November. With the exception of 1 event in early October at the southwest station, recruitment at Homosassa was restricted to the north latitudinal transect. Loss of collectors at Homosassa was inconsequential at all except the central-mid and central-west stations, each of which suffered complete loss of collectors during 1 deployment (Fig. 7).

At Steinhatchee, bay scallop recruitment differed significantly over time $(F=108.32, \mathrm{p}=0.0001)$. Overall, the temporal nature of recruitment was similar among stations at a common depth, but stations along a common latitudinal transect sometimes differed in the timing and rate of recruitment. During the first deployment, recruitment rate was equivalent to the mean of the remaining dates, but significant deviations from the mean occurred on the remaining dates. Recruitment was significantly lower than the mean of the remaining dates during the second and third deployments, significantly higher than the mean of the 

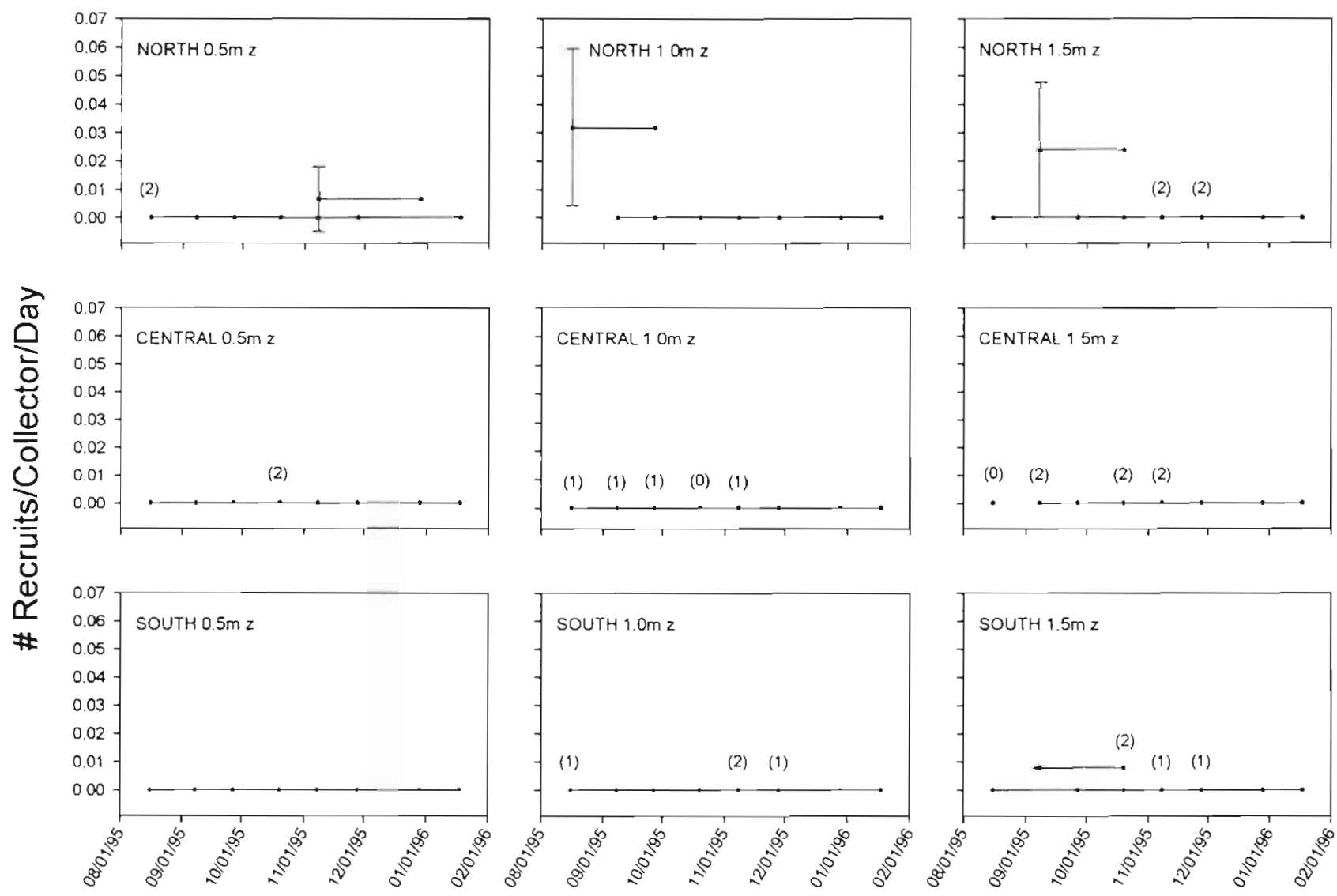

Date

Fig. 7. Recruitment of bay scallops Argopecten irradians to spat collectors deployed at each of 9 stations at the Homosassa study site during August 1995 to January 1996. Spat-collector station locations are arrayed according to latitudinal position and water depth; locations are depicted in Fig. 3. Each 6 wk deployment is denoted by a start-date point, an end-date point, and a line connecting the 2 points. Error bars represent 1 standard deviation from the mean and are positioned at the beginning point of the deployment period they represent. Numbers in parentheses represent number of collectors recovered from that deployment period, are similarly positioned at the beginning point of the deployment period they represent, and are not included for deployments from which all 3 collectors were recovered

remaining dates during the fourth and fifth deployments, then again fell to a low level during the final deployment (Fig. 8). Both the latitudinal position $x$ time $(F=9.81, \mathrm{p}=0.0001)$ and the depth $\times$ time $(F=4.36, \mathrm{p}=$ 0.0012 ) interactions were highly significant, as evidenced by higher overall recruitment at the central latitudinal transect and lower overall recruitment at the shallow stations. Recruitment was essentially 0 at all Steinhatchee stations during the final deployment, a feature shared with most other stations at our other study sites.

Our data and analyses at the St. Joseph Bay study site differed slightly from the Anclote, Homosassa, and Steinhatchee study sites because of the lack of a depth treatment at the former site. Although the location by time interaction was not significant $(F=2.19$, $\mathrm{p}=0.094$ ), suggesting that recruitment events were sampled equally at all stations at this site, recruitment did differ significantly over time $(F=154.06, \mathrm{p}=$ $0.0001)$. Recruitment was significantly lower than the remaining date average during the first 2 deployments, did not differ from the average during the third deployment, was significantly and substantially higher than the remaining date average during the fourth deployment, and was slightly but significantly higher during the fifth deployment before again falling to a below-average value during the final deployment (Fig. 9). Thus, although some recruitment was recorded at all stations during most sampling episodes, we recorded 1 intensive peak of recruitment during October and early November, and this peak was recorded at all stations. That peak represents the highest recruitment rate that we recorded at any site during our study. 

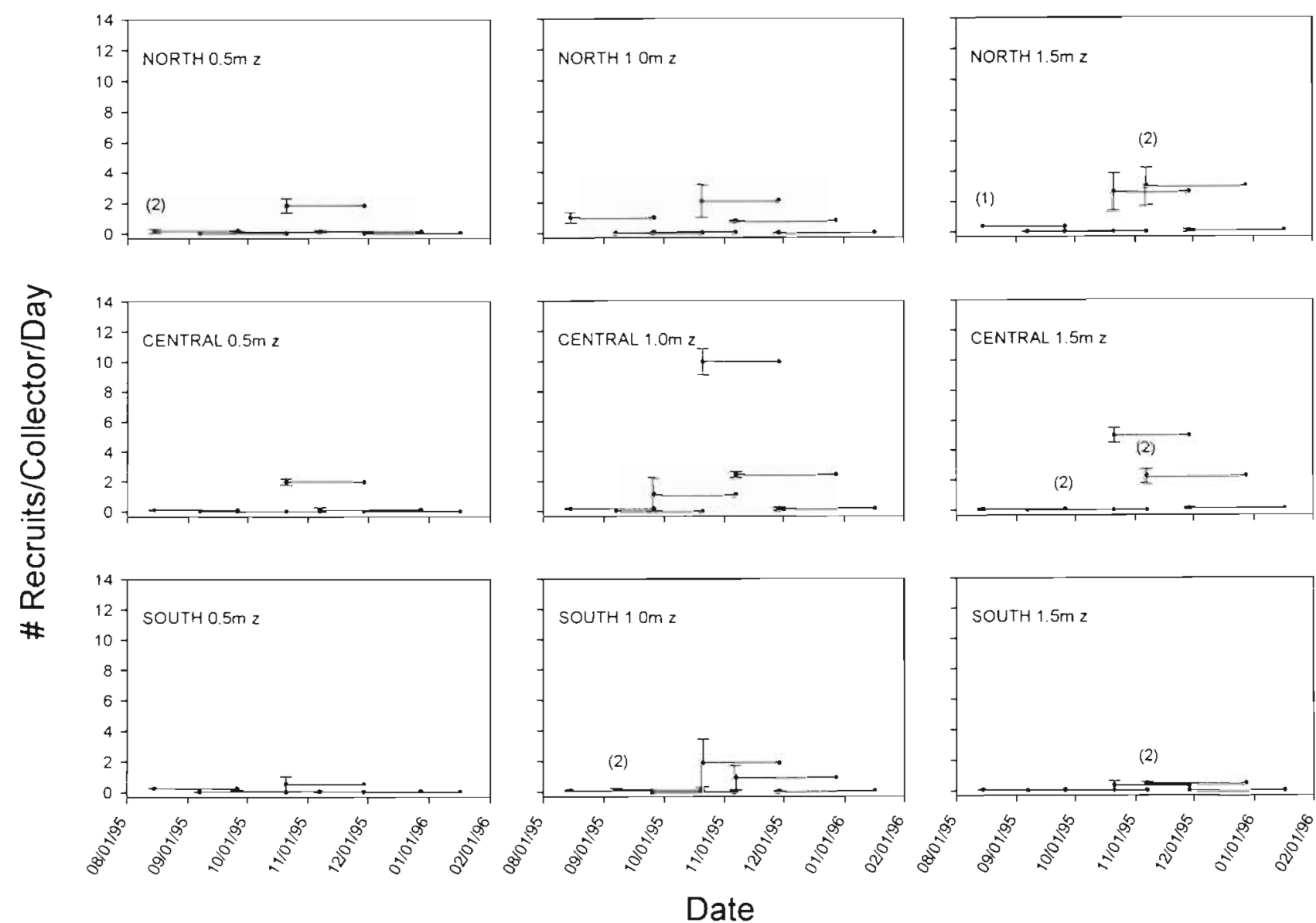

Fig. 8. Recruitment of bay scallops Argopecten irradians to spat collectors deployed at each of 9 stations at the Steinhatchee study site during August 1995 to January 1996. Spat-collector station locations are arrayed according to latitudinal position and water depth; locations are depicted in Fig. 4. Each $6 \mathrm{wk}$ deployment is denoted by a start-date point, an end-date point, and a line connecting the 2 points. Error bars represent 1 standard deviation from the mean and are positioned at the beginning point of the deployment period they represent. Numbers in parentheses represent number of collectors recovered from that deployment period, are similarly positioned at the beginning point of the deployment period they represent, and are not included for deployments from which all 3 collectors were recovered

\section{DISCUSSION}

Abundance of adult bay scallops differed significantly among the 4 sites that we monitored during 1995 and 1996, as did the rate of recruitment of scallops settling to spat collectors. Our results describe a generally positive relationship between the number of adults sampled in June 1995 and June 1996 and the intensity of recruitment measured during the fall of 1995. Adult bay scallops were scarce at our Anclote and Homosassa study sites and rates of recruitment to spat collectors were relatively low, whereas scallops were abundant at our Steinhatchee and St. Joseph Bay study sites and recruitment rates were relatively high. Therefore, the local populations that compose the purported bay scallop metapopulation along the Floridan Gulf of Mexico coast, which we report on in this study, appear to function at a geographic scale similar to that observed for populations from other western Atlantic Ocean estuaries (e.g Peterson \& Summerson 1992, Tettelbach \& Wenczel 1993).

Recruitment was not detectably different among stations within each of our 4 study sites. Temporally distinct recruitment peaks were recorded within each site, and those peaks tended to be quantitatively similar and contemporaneous among stations within each site. For example, peak recruitment of more than 20 spat $\mathrm{d}^{-1}$ occurred at all St. Joseph Bay stations during the October 11 to November 19 deployment. Similarly, peak recruitment was recorded during the November 16 to January 11 deployment at Anclote and that peak was approximately twice the daily rate recorded during any other deployment period. In contrast, patterns of recruitment differed substantially 


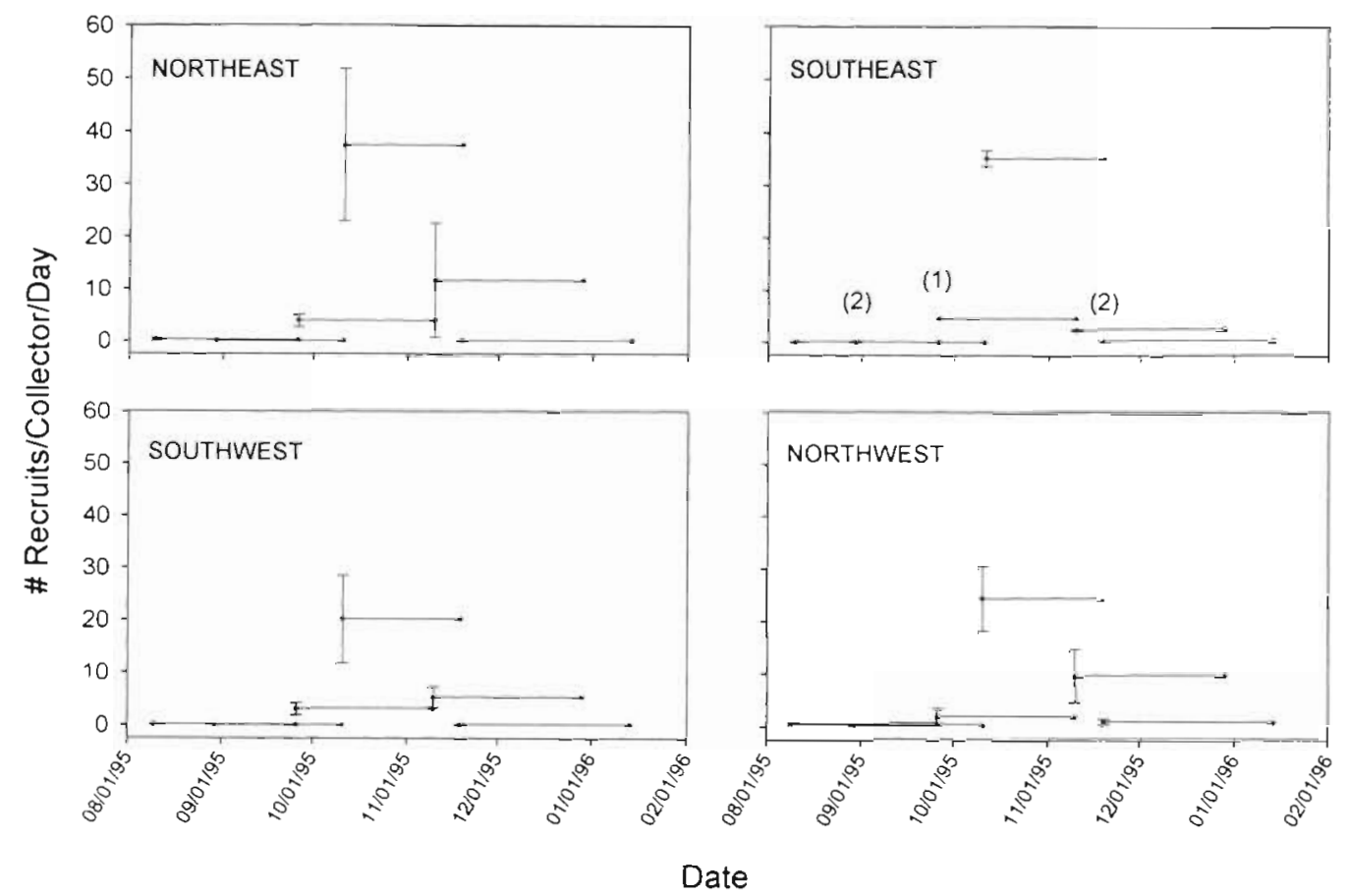

Fig. 9. Recruitment of bay scallops Argopecten irradians to spat collectors deployed at each of 4 stations at the St. Joseph Bay study site during August 1995 to January 1996. Spat-collector station locations are arrayed according to latitudinal position and water depth; locations are depicted in Fig. 5. Each 6 wk deployment is denoted by a start-date point, an end-date point, and a line connecting the 2 points. Error bars represent 1 standard deviation from the mean and are positioned at the beginning point of the deployment period they represent. Numbers in parentheses represent number of collectors recovered from that deployment period, are similarly positioned at the beginning point of the deployment period they represent, and are not included for deployments from which all 3 collectors were recovered

among sites. Peak recruitment rate measured at both Steinhatchee and St. Joseph Bay was approximately 1.5 to 2 orders of magnitude greater than peak recruitment measured at Anclote and Homosassa. Moreover, peak recruitment occurred during the August 16 to September 27 and September 8 to October 20 deployments at Homosassa but during the November 16 to January 11 deployment at Anclote. Therefore, with respect to the relationship between recruitment and adult abundance, our sites appear to function on a scale equivalent to that of North Carolina basins. Strong coherence between adult abundance and the daily rate of recruitment within each of 3 coastal North Carolina basins contrasts sharply with weak coherence between those parameters among basins (Peterson \& Summerson 1992). Our sites also appear to function on a scale similar to that of local bays within the Peconic Bay system of Long Island, New York (Tettelbach \& Wenczel 1993). Bay scallop populations in that system were decimated during the mid- to late 1980 s as a result of a brown tide (Aureococcus anophagefferens) bloom (Cosper et al. 1987). Adult scallop survival varied from 0 to $90 \%$ in the bays that compose that system (Tettelbach \& Wenczel 1993, Wenczel et al. 1993), and larval recruitment was similarly negatively affected (Bricelj et al. 1987, Wenczel et al. 1993). However, some recruitment was apparent from the continued regeneration of scallop year classes in those areas of the Peconic Bay system where mortality was not complete (Wenczel et al. 1993). The estimated $20+d$ retention time of water within each of the sub-bays of the Peconic system (Hardy 1976), coupled with a model of projected larval dispersion within the Peconic Bay system (Siddal et al. 1986), suggests a mechanism for larval retention within those bays and provides support for the hypothesis that at least under certain conditions, self-seeding of those populations does occur.

Self-seeding has been reported for populations of other fish and invertebrate species with planktotrophic larvae, so the potential exists for self-seeding of local populations of bay scallops. For example, drift-tube studies conducted by Levin (1983) provide evidence that larvae of the spionid polychaete Pseudopolydora paucibranchiata, which hydrographically could have been transported more than $200 \mathrm{~km}$ away from their point of origin in Mission Bay, California during their 2 wk larval life span, were predominantly retained within the bay. Tegner \& Butler (1985) used similar 
techniques and determined that most larvae of the green abalone Haliotis fulgens should settle within a few kilometers of the release site. Numerical models suggest that in at least some habitats larval retention does occur (e.g. Black et al. 1990, 1991, Schultz \& Cowen 1994) and also provide evidence of limited particle dispersal along the Florida west coast at least during fall (Weisberg et al. 1996a), when bay scallops spawn.

For the short-lived bay scallop, whose interannual fluctuations in population abundance are well documented (e.g. Rhodes 1991), self-seeding may be necessary for the year-to-year maintenance of discrete local populations. With the exception of the almost completely enclosed St. Joseph Bay, the scallop populations that we studied occupy open coastal habitats and are exposed to water currents that are complex and multidirectional along this coast (Weisberg et al. 1996a). The spatial extent of each of our local populations is approximately equivalent to the total area of the North Carolina sites studied by Peterson and colleagues (e.g. Peterson \& Summerson 1992) and the Peconic Bay, New York, sites studied by Tettelbach and colleagues (e.g. Tettelbach \& Wenczel 1993). However, bay scallop populations that we have identified from Florida coastal waters are isolated from one another by geographic distances of at least $30 \mathrm{~km}$ (Arnold et al. 1997). It therefore appears that geographically adjacent but physically isolated bay scallop populations in North Carolina and New York waters contrast with the apparently physically open but geographically separated bay scallop populations in Florida waters.

Nearshore currents along the Florida west coast may retain particles in the local area, transport particles either north or south along the coast, or even transport particles from point to point via coastal jets that transit the Gulf of Mexico (Yang et al. 1995, Weisberg et al. 1996a). Maximum current speed within these features may be $2.5 \mathrm{~km} \mathrm{~h}^{-1}$ (Yang et al. 1995), providing a potential mechanism for transport of bay scallop larvae among all of our study sites well within the reported 10 to $14 \mathrm{~d}$ planktonic larval phase of Argopecten irradians (Sastry 1965). Over the short term, retention within the local area may be the predominant mechanism for repopulation, and transport of larvae between sites may be rare (Palumbi 1995, Bakun 1996). Over the long term, larvae may occasionally be transported between sites (Bakun 1996), providing seed for reestablishment of depleted populations and for the maintenance of previously reported (Marelli et al. 1997) genetic similarity among local populations (Slatkin 1987).

The coherence between adult abundance and relative recruitment that we describe within each of our local populations supports the idea that larval retention and self-seeding occur in those populations. However, there are alternative explanations. Our results simply may reflect the action of differential post-settlement mortality within collectors among sites, but we consider that alternative unlikely for several reasons. First, we have no reason to suspect that predation, the most likely source of post-settlement mortality within the collectors, is more intense at the Anclote and Homosassa study sites than at Steinhatchee and St. Joseph Bay. We do observe predators such as mud crabs (e.g. Panopeus) and juvenile stone crabs (Menippe spp.) within the collectors, but our estimates of abundance suggest relative equality of those organisms among sites. Second, Ambrose \& Lin (1991) report no difference in post-settlement mortality of Argopecten irradians recruits between laboratory- and fielddeployed collectors in North Carolina waters, suggesting that recruitment to collectors deployed for up to 6 wk does provide a valid index of settlement (Ambrose et a]. 1992). Finally, our results generally reflect similar levels of recruitment among overlapping collectors at each station, a pattern that would not be expected if post-settlement mortality patterns were substantial and temporally biased. We therefore conclude that our collectors provide a valid index of relative settlement of bay scallop larvae among sites along the west coast of Florida.

We can provide other alternatives to the self-seeding hypothesis that invoke the scale and pattern of larval dispersal. For example, it is possible that populations in areas such as Steinhatchee function as source populations (Pulliam 1988) that provide recruits for depleted populations within the range of larval transport (Harrison 1991). The fate of exported larvae is unknown and would be difficult to determine with present technology, but lack of recruits at the Homosassa and Anclote study sites suggests that expatriate larvae were not successfully transported to those sites, or were transported in very low numbers, during fall 1995. Another alternative is that Steinhatchee and St. Joseph Bay simply traded larval masses during fall 1995, but this is unlikely given the generally localized pattern of nearshore currents in this region of Florida (Weisberg et al. 1996a), the enclosed nature of St. Joseph Bay. and the almost complete lack of scallops in apparently suitable habitats between Steinhatchee and St. Joseph Bay during our study period (Arnold et al. 1996). Finally, it is possible that larvae from the Steinhatchee and St. Joseph Bay populations are swept away from the local area and that recruits to those populations are supplied by yet-unidentified source populations. However, our extensive Florida west coast bay scallop surveys (Arnold et al. 1996, 1997) and by-catch reports from commercial trawlers (Coleman et al. 1993, 1994) 
provide no evidence of other dense bay scallop assemblages in nearshore Florida waters. During our study, only Steinhatchee and St. Joseph Bay appeared to support high-density (>5 scallops per $600 \mathrm{~m}^{2}$ ) bay scallop populations in Florida waters, and only those sites received substantial numbers of settling scallop larvae.

Various oceanographic features may operate, either individually or in concert, to retain larvae within the local area. For example, the area between Anclote and St. Joseph Bay appears to function hydrographically as an isolated bay (Austin \& Jones 1974). This 'bay' is defined by an eddy system operating shoreward of a line drawn between Anclote and St. Joseph Bay (generally within the $20 \mathrm{~m}$ isobath) and is separated from the Gulf of Mexico by seasonally oscillating coastal jets (Yang et al. 1995). Within this hydrographically defined bay, tidal oscillations that have excursions of less than $1 \mathrm{~km}$ under fall conditions along the Florida west coast (Weisberg et al. 1996a) may influence retention of larvae within the nearshore zone (Shanks 1986). Alternatively, upwelling-downwelling cycles that may develop in response to the passage of cold fronts could function to retain larvae within the local area. Although random movement of larvae within a water mass will operate to spread those larvae over a relatively large area even within a well-defined water mass, only a small proportion of the total larval pool is necessary to replenish even the most abundant Florida scallop population (Bakun 1996).

The scenario that we describe for retention of bay scallop larvae within the local habitat is not yet definitive. We are conducting allozyme electrophoretic and mt.DNA studies to better define the interrelation of local bay scallop populations along the Florida west coast. We also have developed and tested a genetic probe that we will use to define the spatial distribution of scallop larvae around nodes of adult scallop abundance. The results of those studies, coupled with better information on the short-term dynamics of nearshore circulation along the west Florida shelf (Weisberg et al. 1996b). will be instrumental in determining the relative importance of local versus long-distance dispersal of larvae along the Gulf of Mexico coast of Florida to the maintenance of local populations of Argopecten irradians. Such information will be a necessary component of the effective restoration and management of this important marine resource.

Acknowledgements. Field and laboratory assistance was ably provided by Kate Hagner, Philip Hoffman, Tracy Wade, Justin Styer, John Gunter, and James Marshall. Gil McRae assisted with statistical analyses, and Bob Brock assisted with literature research. Steve Tettelbach provided information on Peconic Bay, New York. We thank Julie Wallin, Rich McBride, Charles Peterson, and 2 anonymous referees for reviewing preliminary drafts of the manuscript.

\section{LITERATURE CITED}

Ambrose WG Jr, Lin J (1991) Settlement preference of Argopecten irradians (Lamarck 1819) larvae for artificial substrata. In: Shumway SE, Sandifer PA (eds) An international compendium of scallop biology and culture. World Aquaculture Society, Baton Rouge, LA, p 16-20

Ambrose WG $\mathrm{J}_{\mathrm{r}}$, Peterson $\mathrm{CH}$, Summerson HC, Lin J (1992) Experimental tests of factors affecting recruitment of bay scallops (Argopecten irradians) to spat collectors. Aquaculture 108:67-86

Arnold WS, Marelli DC, Bray C, Harrison M, Hoffman P, Hagner K, Styer J (1996) Annual report of the bay scallop project, 1995. Florida Department of Environmental Protection Florida Marine Research Institute, St. Petersburg

Arnold WS, Marelli DC, Hagner K, Harrison M, Hoffman P (1997) Annual report of the bay scallop project, 1996. Florida Department of Environmental Protection Florida Marine Research Institute, St. Petersburg

Austin HM, Jones JI (1974) Seasonal variation of physical oceanographic parameters on the Florida Middle Ground and their relation to zooplankton biomass on the west Florida shelf. Fla Sci 37:16-32

Bakun A (1996) Patterns in the ocean: ocean processes and marine population dynamics. US Department of Commerce, National Oceanic and Atmospheric Administration, California Sea Grant College System, La Paz

Barber BJ, Blake NJ (1983) Growth and reproduction of the bay scallop, Argopecten irradians (Lamarck) at its southern distributional limit. J Exp Mar Biol Ecol 66:247-256

Bertness MD, Gaines SD, Stephens EG, Yund PO (1992) Components of recruitment in populations of the acorn barnacle Semibalanus balanoides (Linnaeus). J Exp Mar Biol Ecol 156:199-215

Black KP, Gay SL, Andrews JC (1990) Residence times of neutrally-buoyant matter such as larvae, sewage or nutrients on coral reefs, Coral Reefs 9:105-114

Black KP, Moran PJ (1991) Influence of hydrodynamics on the passive dispersal and initial recruitment of larvae of Acanthaster planci (Echinodermata: Asteroidea) on the Great Barrier Reef. Mar Ecol Prog Ser 69:55-65

Black KP, Moran PJ, Hammond LS (1991) Numerical models show coral reefs can be self-seeding. Mar Ecol Prog Ser 74:1-11

Brand AR, Paul JD, Hoogesteger JN (1980) Spat settlement of the scallops Chlamys opercularis (L.) and Pecten maximus (L.) on artificial collectors. J Mar Biol Assoc UK 60:379-390

Bricelj VM, Epp J, Malouf RE (1987) Intraspecific variation in reproductive and somatic growth cycles of bay scallops Argopecten irradians. Mar Ecol Prog Ser 36:123-137

Butman CA (1987) Larval settlement of soft-sediment invertebrates: the spatial scales of pattern explained by active habitat selection and the emerging role of hydrodynamical processes. Oceanogr Mar Biol Annu Rev 25:113-165

Chanley P, Andrews JD (1971) Aids for identification of bivalve larvae of Virginia. Malacologia 11:45-119

Coleman FC, Koenig CC, Herrnkind WF (1993) Survey of Florida inshore shrimp trawler by-catch. Annual report, Florida Department of Natural Resources, DNR contract \#C-7779, Tallahassee, FL

Coleman FC, Koenig CC, Herrnkind WF (1994) Survey of Florida inshore shrimp trawler by-catch. Second annual report, Florida Department of Natural Resources, DNR contract \#C-7779, Tallahassee, FL

Cosper EM, Dennison WC, Carpenter EJ, Bricelj VM, Mitchell JG, Kuenstner SH, Colflesh D, Dewey M (1987) Recurrent and persistent brown tide blooms perturb coastal marine ecosystem. Estuaries 10:284-290 
Day RW, Quinn GP (1989) Comparisons of treatments after an analysis of variance in ecology. Ecol Monogr 59:433-463

Gaines SD, Bertness MD (1992) Dispersal of juveniles and variable recruitment in sessile marine species. Nature 360:579-580

Gaines S, Brown S, Roughgarden J (1985) Spatial variation in larval concentrations as a cause of spatial variation in settlement for the barnacle, Balanus glandula. Oecologia 67 : $26 \overrightarrow{7}-272$

Gaines S, Roughgarden J (1985) Larval settlement rate: a leading determinant of structure in an ecological community of the marine intertidal zone. Proc Natl Acad Sci USA 82:3707-3711

Grosberg RK, Levitan DR (1992) For adults only? Supply-side ecology and the history of larval biology. Trends Ecol Evol $7: 130-133$

Hanski I (1991) Single-species metapopulation dynamics: concepts, models and observations. Biol J Linn Soc 42 : $17-38$

Hanski I, Simberloff D (1997) The metapopulation approach, its history, conceptual domain, and application to conservation. In: Hanski IA, Gilpin ME (eds) Metapopulation biology: ecology, genetics, and evolution. Academic Press, San Diego, p 5-26

Hardy CD (1976) A preliminary description of the Peconic Bay estuary. Mar Sci Res Center, State Univ New York, Spec Rep 3, Reference 76-4

Harrison S (1991) Local extinction in a metapopulation context: an empirical evaluation. Biol J Linn Soc 42:73-88

Harvey M. Bourget E, Gagne N (1997) Spat settlement of the giant scallop, Placopecten magellanicus (Gmelin, 1791). and other bivalve species on artificial filamentous collectors coated with chitinous material. Aquaculture 148: $277-298$

Harvey M, Bourget E, Legault C, Ingram RG (1995) Shortterm variations in settlement and early spat mortality of Iceland scallop, Chlamys islandica (O.F. Müller). J Exp Mar Biol Eccl 194:167-187

Keough MJ, Downes BJ (1982) Recruitment of marine invertebrates: the role of active larval choices and early mortality. Oecologia 54:348-352

Knowlton N, Keller BD (1986) Larvae which fall far short of their potential: highly localized recruitment in an alpheid shrimp with extended larval development. Bull Mar Sci 39:213-223

Levin LA (1983) Drift tube studies of bay-ocean water exchange and implications for larval dispersal. Estuaries 6 : $364-371$

Levins R (1969) Some demographic and genetic consequences of environmental heterogeneity for biological control. Bull Entomol Soc Am 15:237-240

Lewin R (1986) Supply-side ecology. Science 234:25-27

Lewis RR, Durako MJ, Moffler MD, Phillips RC (1985) Seagrass meadows of Tampa Bay - a review. In: Treat SAF, Simon JL, Lewis RR III, Whitman RL Jr (eds) Proceedings Tampa Bay Area Scientific Information Symposium. Fla Sea Grant Coll, Rep 65:210-246

Littell RC, Freund RJ, Spector PC (1991) SAS systems for linear models, 3rd edn. SAS Institute, Cary, NC, p 248-249

Marelli DC, Krause MK, Arnold WS, Lyons WG (1997) Systematic relat:onships among Florida populations of Argopecten irradians (Lamarck, 1819) (Bivalvia: Pectinidae). Nautilus 110:31-41.

Milicich MJ, Meekan MG, Doherty PJ (1992) Larval supply: a good predictor of recruitment of three species of reef fish (Pomacentridae). Mar Ecol Prog Ser 86:153-166

Minchinton TE, Scheibling RE (1991) The influence of larval supply and settlement on the population structure of barnacles. Ecology 72:1867-1879

Olafsson EB, Peterson CH, Ambrose WG Jr (1994) Does recruitment limitation structure populations and communities of macro-invertebrates in marine soft-sediments: the relative significance of pre- and post-settlement processes. Oceanogr Mar Biol Annu Rev 32:65-109

Olson RR (1985) The consequences of short-distance larval dispersal in a sessile marine invertebrate. Ecology 66: $30-39$

Orensanz JM, Parma AM, Iribarne OO (1991) Population dynamics and management of natural stocks. In: Shumway SE (ed) Scallops: jiology, ecology and aquaculture. Elsevier, New York, p 625-713

Palmer AR, Strathmann RR (1981) Scale of dispersal in varying environments and its implications for life histories of marine invertebrates. Oecologia 48:308-318

Palumbi SR (1995) Using genetics as an indirect estimator of larval dispersal. In: McEdward L (ed) Ecology of marine invertebrate larvae. CRC Press, Boca Raton, FL, p 369-387

Parsons GJ, Dadswell MJ, Roff JC (1993) Influence of biofilms on settlement of sea scallop, Placopecten magellanicus (Gmelin. 1791), in Passamaquoddy Bay, New Brunswick. Canada. J Shellfish Res 12:279-283

Parsons KE (1996) The genetic effects of larval dispersal depend on spatial scale and habitat characteristics. Mar Biol 126:403-414

Peterson CH, Summerson HC (1992) Basin-scale coherence of population dynamics of an exploited marine invertebrate, the bay scallop: implica:ions of recruitment limitation. Mar Ecol Prog Ser 90:257-272

Peterson CH, Summerson HC, Luettich RA Jr (1996) Response of bay scallops to spawner transplants a test of recruitment limitation. Mar Ecol Prog Ser 132:93-107

Pulliam HR (1988) Sources, sinks, and population regulation. Am Nat 132:652-661

Rhodes EW (1991) Fisheries and aquaculture of the bay scallop. Argopecten irradians, in the eastern United States. In: Shumway SE (ed) Scallops: biology, ecology and aquaculture. Elsevier, New York, p 913-924

Roughgarden JS, Gaines S, Possingham H (1988) Recruitment dynamics in complex life cycles. Science 241:1460-1466

SAS Institute (1996) SAS/STAT user's guide version 6 edn. SAS Institute, Cary, NC

Sastry AN (1965) The development and external morphology of pelagic larval and post-larval stages of the bay scallop, Aequipecten irradians concentricus Say, reared in the laboratory. Bull Mar Sci 15:417-435

Scheltema RS (1971) Larval dispersal as a means of genetic exchange between geographically separated populations of shallow-water benthic marine gastropods. Biol Buil 140: $284-322$

Schultz ET, Cowen RK (1994) Recruitment of coral-reef fishes to Bermuda: local retention or long-distance transport? Mar Ecol Prog Ser 109:1.5-28

Shanks AL (1986) Tidal periodicity in the daily settlement of intertidal barnacle larsde and an hypothesized mechanism for the cross-shelf transport of cyprids. Biol Bull 170: $429-440$

Siddal SE, Vieira ME, Gomez-Reyes E, Pritchard DW (1986) Numerical model of larval dispersion: phase I of the East End algal bloom program. Mar Sci Res Center, State Univ of New York

Slatkin M (1987) Gene flow and the geographic structure of natural populations. Science 236:787-792

Snelgrove PVR, Butman CA. (1994) Animal-sediment relation- 
ships revisited: cause versus effect. Oceanogr Mar Biol Annu Rev 32:111-177

Sokal RR, Rohlf FJ (1995) Biometry: the principles and practice of statistics in biological research, 3rd edn. WH Freeman, New York

Summerson HC, Peterson CH (1990) Recruitment fallure of the bay scallop. Argopecten irradians concentricus, during the first red tide, Ptychodiscus brevis, outbreak recorded in North Carolina. Estuaries 13:322-331

Sutherland JP (1990) Recruitment regulates demographic variation in a tropical intertidal barnacle. Ecology 71. 955-972

Tegner MJ, Butler RA (1985) Drift-tube study of the dispersal potential of green abalone (Haliotis fulgens) larvae in the southern California Bight: implications for recovery of depleted populations. Mar Ecol Prog Ser 26:73-84

Tettelbach ST, Wenczel P (1993) Reseeding efforts and the status of bay scallop Argopecten irradians (Lamarck, 1819) populations in New York following the occurrence of 'brown tide' algal blooms. J Shellfish Res 12:423-431

Thorson G (1950) Reproductive and larval ecology of marine bottom invertebrates. Biol Rev 25:1-45

Underwood AJ, Fairweather PG (1989) Supply-side ecology and benthic marine assemblages. Trends Ecol Evol 4:16-20

Waller TR (1969) The evolution of the Argopecten gibbus stock (Mollusca: Bivalvia), with emphasis on the tertiary

Editorial responsibility: Charles Peterson (Contributing Editor), Morehead City, North Carolina, USA and quatemary species of eastern North America. J Paleontol 43:1-125

Weisberg RH, Black BD, Yang H (1996a) Seasonal modulation of the west Florida continental shelf circulation. Geophys Res Lett 23:2247-2250

Weisberg RH, Yang H, Black BD, Li Z, siegel E, Cole R, Donovan J (1996b) West-central Florida shelf hydrography and circulation. In: Gelfenbaum G (ed) Second west-central Florida coastal studies workshop. United States Geological Survey Center for Coastal Geology, St. Petersburg, FL, p 11-20

Wenczel P, Smith C, Tettelbach S (1993) Planting bay scallops: results of reseeding bay scallops in the Peconic Bay, New York, 1986 to 1992. Final report submitted to the New York State Urban Development Corporation, the New York State Department of Environmental Conservation, and Suffolk County, New York

Yang $\mathrm{H}$, Weisberg RH, Black BD (1995) Numerical investigations on the three-dimensional west Florida shelf circulation. In: Gelfenbaum G (ed) First west-central Florida coastal studies workshop. United States Geological Survey Center for Coastal Geology, St. Petersburg, FL, p 38-45

Young CM (1987) Novelty of 'supply-side ecology'. Science $235: 415-416$

Zar JH (1996) Biostatistical analysis, 2nd edn. Prentice Hall, Englewood Cliffs, NJ

Submitted: February 6, 1998; Accepted: May 21, 1998 Proofs received from author(s): August 19, 1998 